\title{
The importance of vitamin-D in androgenic alopecia and telogen effluvium
}

\section{Gülbahar Saraç', Tuba Tülay Koca ${ }^{2}$ \\ ${ }^{1}$ Department of Dermatology, Faculty of Medicine, Inonu University, Malatya, Turkey \\ ${ }^{2}$ Department of Physical Medicine and Rehabilitation, Faculty of Medicine, Sütçü İmam University, Kahramanmaraş, Turkey}

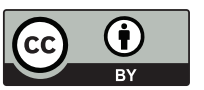

This work is licensed under a Creative Commons Attribution 4.0 International License

Received: 2018-09-05

Accepted: 2018-10-09

UDC: 616.1

\section{J Clin Med Kaz 2018;4(50):26-29}

Corresponding Author: Tuba Tülay KOCA, Assistant Professor, Department of Physical MedicIne and Rehabilitation, Sütçü İmam University,

Kahramanmaraș, Turkey. Phone: +90 5063819295

E-mail: tuba_baglan@yahoo.com

\section{Abstract}

Aim: Androgenic alopecia (AA) is defined as progressive miniaturization of scarless hair follicle prevailing among both male and female. Telogen effluvium (TE) is the most common hair loss form accompanying systemic diseases. It is aimed to determine the role of vitamine $\mathrm{D}$, the significance of which has been increasing in recent years, in hair loss problem within the scope of this study.

Methods: The patients who applied to Dermatology clinic with the complaint of hair loss and diagnosed androgenic alopecia and telogen effluvium by clinic examination between the years 2015-2016 were included into this study. The age, gender and 25'OHvitamin-D level of the patients were recorded retrospectively.

Results: One-hundred eighty seven $(\mathrm{N}=187)$ participants (140 female / 47 male) were included in this study. Fifty-eight $(\mathrm{N}=58)$ patients $(28$ female / 30 male) with androgenic alopecia diagnosis formed the first group; 71 patients ( 65 female / 6 male) with telogen effluvium were formed the second group and 58 healthy volunteers (47 female / 11male) were included in the control group. When Vitamin-D level of first group (AA) was compared with that of the second group (TE) and the control group, there was a statistically significant difference observed $(\mathrm{p}=0.01 / \mathrm{p}=0.01$ respectively). However, there was no statistically significant difference between the vitamin-D level of second group (TE) and that of the healthy control group $(\mathrm{p}=0.61)$.

Conclusion: The level of $25^{\prime}(\mathrm{OH})$ vit D was found high in androgenic alopecia group than telogen effluvium and controls. Revealing the relationship between vitamin-D level and hair loss might give us the opportunity to come up with new treatment options considering refractory patients.

Keywords: vitamin D, telogen effluvium, androgenic alopecia

\section{АНДРОГЕНДІК ЖӘНЕ ТЕЛОГЕНДІК АЛОПЕЦИЯДАҒЫ D ВИТАМИНІНІН РӨЛІ \\ Гульбахар Сарач ${ }^{1}$, Туба Тюлай Коджа ${ }^{2}$ \\ ${ }^{1}$ Дерматология кафедрасы, Медицина факультеті, Инёню атындағы Университет, Малатья, Түркия \\ ${ }^{2}$ Физиотерапия және оңалту кафедрасы, Сутчу Имам университеті, Кахраманмараш, Түркия}

\section{ТҰЖЫРЫМДАМА}

Кіріспе: Андрогенді алопеция (АА) ерлер мен әйелдер арасында басым болып табылатын кебексіз шаш фолликулының прогрессивті миниатюризациясы ретінде анықталады. Телогенді алопеция (ТА) - бұл жүйелі ауруларға сәйкес келетін шаш түсуінің кең таралған түрі. Бұл зерттеудің мақсаты шаш түсу мәселесі аясында соңғы жылдары мәні артып келе жатқан D витаминінің рөлін анықтау болып табылады.

Әдістері: Бұл зерттеуге 2015-2016 жылы дерматологиялық клиникаға шаш түсуіне шағымданған және клиникалық тексеруден кейін андрогенді немесе телогенді алопецияны диагностикаланған пациенттер еңгізілді. Емделушілердің жасы, жынысы және D витаминінің 25-OH деңгейі ретроспективті тіркелді.

Нәтижелері: Жүз сексен жеті (N=187) қатысушы (140 әйел / 47 ер) зерттеуге еңгізілді. Андрогенді алопеция диагнозы бар елу сегіз $(\mathrm{N}=58)$ пациент (28 әйел / 30 ер) бірінші топқа кірді, 71 пациент (65 әйел / 6 ер адам) телогенді алопеция диагнозымен екінші топқа және 58 дені сау ерікті адам (47 әйел / 11 ер адам) бақылау тобына кірді. Бірінші топтағы D витаминінің (AA) деңгейін екінші топпен (TA) және бақылау тобымен салыстырғанда статистикалық мәнді айырмашылық байқалды ( $p=0.01 / p=0.01$ сәйкесінше). Алайда, екінші топ (TA) мен сау бақылау тобы ( $\mathrm{p}=0.61)$ витаминінің деңгейі арасында айтарлықтай айырмашылық болған жоқ.

Қорытынды: D витаминінің 25-OH деңгейі телогенді алопеция тобына және бақылау тобына қарағанда андрогенді алопеция тобында жоғары болды. D витаминінің шаш түсу арасындағы өзара байланысын анықтау бізге рефрактерлік пациенттерді емдеудің жаңа нұсқаларын әзірлеуге мүмкіндік береді.

Негізгі сөздер: D витамині, телогенді алопеция, андрогендік алопеция

\section{РОЛЬ ВИТАМИНА D ПРИ АНДРОГЕННОЙ И ТЕЛОГЕНОВОЙ АЛОПЕЦИИ}

\section{Гульбахар Сарач ${ }^{1}$, Туба Тюлай Коджа}

${ }^{1}$ Кафедра дерматологии, Факультет медицины, Университет имени Инёню, Малатья, Турция

${ }^{2}$ Кафедра физиотерапии и реабилитации, Университет Сутчу Имам, Кахраманмараш, Турция

\section{РЕЗЮМЕ}

Введение: Андрогенная алопеция (AА) определяется как прогрессивная миниатюризация безрубцового волосяного фолликула, преобладающая среди мужчин и женщин. Телогеновая алопеция (ТА) это наиболее распространенная форма выпадения волос, 
сопутствующая системным заболеваниям. Целью данного исследования является определение роли витамина D, значение которого увеличивается в последние годы в рамках проблемы выпадения волос.

Методы: В данное исследование были включены пациенты, которые обращались в дерматологическую клинику в $2015-2016$ году с жалобами на выпадение волос и у которых после клинического обследования диагностировали андрогенную или телогеновую алопецию. Возраст, пол и уровень 25-ОН витамина D пациентов были зарегистрированы ретроспективно.

Результаты: Сто восемьдесят семь (N=187) участников (140 женщин / 47 мужчин) были включены в исследование. Пятьдесят восемь ( $\mathrm{N}=58)$ пациентов (28 женщин / 30 мужчин) с диагнозом андрогенная алопеция вошли в первую группу; 71 пациент (65 женщин / 6 мужчин) с диагнозом телогеновая алопеция вошли во вторую группу и 58 здоровых добровольцев (47 женщин / 11 мужчин) вошли в контрольную группу. При сравнении уровня витамина D первой группы (AA) со второй группой (ТА) и контрольной группой, наблюдалась статистически значимая разница ( $p=0.01 / p=0.01$ соответственно). Однако, значительной разницы между уровнем витамина D второй группы (ТA) и здоровой контрольной группы не было ( $p=0.61)$.

Заключение: Уровень 25-ОН витамина D был выше в группе андрогенной алопеции, чем в группе телогеновой алопеции и контрольной группе. Выявление взаимосвязи между витамином D и выпадением волос может дать нам возможность разработать новые варианты лечения рефрактерных пациентов.

Ключевые слова: витамин D, телогеновая алопеция, андрогенная алопеция

\section{Introduction}

Androgenic alopecia (AA) is defined as progressive miniaturization of non-scatrisyel alopecia hair follicle prevailing among both male and female. Level of androgene, age and genetic factors have been stated as the primary causes concerning pathogenesis of the disease [1]. However, the loss of hair has seemed prevalent among genetically prone individuals even with normal androgenic hormone level [2]. The occurrence and development of AA depends on the interaction of endocrine factors and genetic predisposition [3]. Its pathogenesis is androgen dependent, and genetic predisposition is the major requirement for the phenotype [4]. Although AA is a very prevalent condition, approved therapeutic options are limited. Finasteride and minoxidil for male AA and minoxidil for female AA still are the therapeutic options with the highest level evidence [5].

One of the common causes of diffuse hair loss, telogen effluvium (TE) is also the most common pattern that can be characterized with common telogene hair shedding [6]. It was first described by Kligman in 1961. Women with TE more frequently present to dermatologist. A wide variety of potential triggers have been implicated in the pathogenesis of TE [7]. In its acute form, it generates a lot of anxiety in the patient, which can be significantly allayed with a confident diagnosis. In its more chronic form, however, the hair loss may go unnoticed for long periods of time [8]. Chronic TE is most often intermittent, alternating periods of spontaneous remissions with episodes of unexplained relapses [9].

As any disturbances in the hair follicle cycle may lead to hair shedding, or alopecia, the possible role of vitamin D in alopecia was investigated in many studies. A growing body of evidence shows that vitamin D and its receptor are responsible for maintaining not only calcium homeostasis but also skin homeostasis [10]. Here, we aimed to determine the role of vitamin $\mathrm{D}$, the significance of its roles has been increasing in recent years, in hair loss problem within the scope of this study.

\section{Material and methods}

The patients who applied to Dermatology clinic with the complaint of hair loss and diagnosed AA/ TE by clinic examination between the years April 2015 - April 2016 were included into this study. With a prior written consent form taken from the participants, they were divided into three main categories according to diagnosis: the first group consisted of the ones with AA, the second group was formed with the ones with TE and the last group included the ones with no distinct diagnosis (healthy control group). The age, gender and 25' $(\mathrm{OH})$ vitamin-D level of the patients were recorded retrospectively. Complete blood count, thyroid function test, Vit B 12, folic acid, ferritin and zinc levels recorded from hospital data. Patients detected any abnormalities from these tests were excluded from the study.

Statistical analysis of the study was performed with SPSS 17 (SPSS Statistics for Windows, Version 17.0. Chicago: SPSS Inc). Normal distribution analysis of the data acquired was evaluated with Kolmogorov-Smirnov test method. Descriptive tests were used for the defining data. Independent student T-test was used for the comparison of groups with normal distribution, and Mann Whitney U test was applied for the comparison of groups with non-central distribution. $\mathrm{P}<0.05$ was regarded as statistically significant.

\section{Results}

One-hundred eighty seven $(\mathrm{N}=187)$ participants (140 female / 47 male) were included in this study. Fifty-eight $(\mathrm{N}=58)$ patients (28 female / 30 male) with AA diagnosis formed the first group; 71 patients (65 female / 6 male) with TE formed the second group and 58 healthy volunteers (47 female / 11 male) were included in the control group. For the AA group, the mean age was $30.3 \pm 8.8$ years with a mean $25^{\prime} \mathrm{OH}$ Vitamin-D level of $16.02 \pm 8.3 \mathrm{ng} / \mathrm{dl}$; for the TE group, the mean age was $26.6 \pm 8.4$ years with a mean $25^{\prime}(\mathrm{OH})$ vit D level of $11.6 \pm 5.2 \mathrm{ng} /$ $\mathrm{dl}$; the mean age of the control group was $28.5 \pm 10.1$ years with a mean $25^{\prime}(\mathrm{OH})$ vit D level of $12.2 \pm 8.3 \mathrm{ng} / \mathrm{dl}$. The age, gender and $25^{\prime}(\mathrm{OH})$ vitamin-D level of the groups are shown in Table 1.

Table 1 Distribution of $25^{\prime} \mathrm{OH}$ Vitamin- D, age, gender according to the groups

\begin{tabular}{|l|l|l|l|}
\hline Group & Age (Median) & $25^{\prime}(\mathrm{OH})$ Vit D (Mean \pm SD) & Gender (N/\%) \\
\hline AA (N=58) & 30 & $16.02 \pm 8.3(\uparrow)$ & $\begin{array}{l}\text { F 30/51.7 } \\
\text { M 28/48.3 }\end{array}$ \\
\hline TE (N=71) & 26 & $11.6 \pm 5.2$ & $\begin{array}{l}\text { F 65/91,5 } \\
\text { M 6/8,5 }\end{array}$ \\
\hline Control (N=58) & 28 & $12.2 \pm 8.3$ & $\begin{array}{l}\text { F 47 /81 } \\
\text { M 11/19 }\end{array}$ \\
\hline
\end{tabular}

Abbreviations: AA: Androgenic alopecia; TE: Telogen effluvium; F: female; M: male; 
When vitamin-D level of the first group (AA) was compared with that of the second group (TE) and the control group, there was a statistically significant difference observed ( $p=0.01 / p=0.01$ respectively) (Table 2 ). However, there was no statistically significant difference between the vitamin-D level of second group (TE) and control group $(\mathrm{p}=0.61)$.

\section{Table 2 Comparisons of vit D levels according to the} groups

\begin{tabular}{|l|l|l|l|}
\hline & Group 1-2 & Group 1-3 & Group 2-3 \\
\hline Age & $\mathrm{P}=0.15$ & $\mathrm{P}=0.294$ & $\mathrm{P}=0.247$ \\
\hline Gender & $\mathrm{P}=0.058$ & $\mathrm{P}=0.080$ & $\mathrm{P}=0.080$ \\
\hline $25^{\prime}(\mathrm{OH})$ Vit D & $\mathrm{P}=0.01^{*}$ & $\mathrm{P}=0.01^{*}$ & $\mathrm{P}=0.61$ \\
\hline
\end{tabular}

Abbreviations: group 1: androgenic alopecia; group 2: telogen effluvium; group 3: control $* P<0.05$, statistically significant.

\section{Discussion}

Hair loss is one of the major reasons among all the patients applying to Dermatology clinic. It has a considerable influence on social interactions among people as most people indicate that hair loss can have adverse effects on their self-confidence and self-esteem. People with hair loss are rather inclined to feel older than they actually are, and they are quite often abstained from daily interactions both socially and physically. Therefore, it can be concluded that alopecia has more diverse effects than assumed for individuals who suffer from this disease as it causes stress along with a dissatisfaction with the body image. As a result of a foresaid desperate situations, millions of dollars are being spent for its treatment every year [11, 12].

Level of androgene, age and genetic factors have been stated as the primary causes concerning pathogenesis of the disease [13]. Telogen effluvium is the most common hair loss form accompanying systemic diseases. On all over the scalp, hair becomes diffusely sparse [8]. There are several factors which might play important role in TE, such as iron deficiency, thyroid gland dysfunctions, systemic diseases, some varieties of medication, hypoproteinemia and low zinc level [14, 15]. Despite the fact that there is no efficient treatment for AA and TE, cause-oriented treatments should be administered after doing necessary tests.

Vitamin-D has a key role in the regulation of calcium homeostasis and bones metabolism. Over the last two decades, immune-regulatory effects of Vitamin-D has arisen everincreasing curiosity with respect to the emergence of some diseases characterized by inflammation, malignancy, autoimmune disorders and chronic infections due to its deficiency [16].

Vitamin-D also plays a vital role in many dermatologic cases. It is used in the treatment of psoriasis for its antiproliferative effect, in healing vitiligo for its melanocytes synthesis stimulating effect and as a remedy for scleroderma and generalize morphea due to its effect of decreasing the collagen synthesis and inhibiting active T-cells functions [17-19]. Wegienka et al have identified significant relevance between the 25-OH vitamin-D levels in prenatal cord blood and some eczema types [20]. They have also discussed that vitamin-D supplement might become a current issue as it can be used for preventive treatment in progress of allergic diseases. In another study conducted, it was contemplated that vitamin-D has important role within the progress, severity and process of some allergic diseases such as asthma, eczema and food allergies. It has also been suggested that extensive vitamin-D deficiency in all over the world can account for the increase of allergic diseases to a certain extent within the last 50-60 years [21].

Vitamin-D has a notable role in the keratinocyte differentiation and forming healthy hair cycle. The intense presence of vitamin-D receptor, the lack of which can affect hair growth, has been identified in hair follicles [22]. It has been claimed by Mady LJ et al. in their experimental animal model that calbindin-D9k knockout pump, maternal vitamin-D deficiency or low calcium diet cause alopecia with no temporary scar [23]. Accordingly, in another experimental animal study conducted by Xie $\mathrm{Z}$ et al, it has been found that there is a relation between insufficient activity of vitamin-D receptors and reduced epidermal differentiation as well as the growth of hair follicles [24]. In yet another study, the findings have posed that the mice whose vitamin-D receptor was mutantized alopecia monitoring the role of vitamin-D receptor was stronger than that of the hormone itself, while alopecia was not a frequent symptom in the case of mice fed on vitamin-D poor diet [25].

In a study conducted on by Mahamid $\mathrm{M}$ et al., low vitamin-D level was detected in alopecia areata patients [26]. In another study conducted by Fawzi et al, it was found that vitamin-D receptor levels in serum and tissue were relatively low in patients with AA and alopecia areata in pathogenesis of which vitamin-D receptors are of vital importance [27]. Apart from the literature according to our study the level of Vit D was statistically higher than the control group and TE group. Yet another study conducted by $\mathrm{H}$ Rasheed et al. on 80 female patients suffering from hair loss with TE diagnosis has revealed a strong correlation between low serum vitamin-D and ferritin level and hair loss occurred [28]. With the realization of this relationship, the importance of vitamin-D and iron supplements in the treatment of hair loss problem will be better appreciated. We did not detect any statistically difference of Vit D levels between TE and control group. There may be other factors (age, gender, etc.) affecting the level of Vit D in TE group.

The correlation between vitamin-D level and alopecia has been more widely established in alopecia areata within the literature. There have been only limited number of studies related to AA and TE. In this study statistically significant vitamin-D level has been found in AA group when compared to that of the healthy control group. On the other hand, there was no statistically significant difference between the vitamin-D level of TE group and that of the healthy control group. Of 58 healthy volunteers within the control group 47 were female and 11 were male. Owing to cultural values and clothing habits in our society, the vitamin-D level of female was found to be lower. Uneven sampling distribution of male and female in our study can be regarded as one of the vulnerabilities. We consider this uneven sampling distribution might have affected the findings and results of this study.

\section{Limitation of the study}

Not considering other bone turnover biomarkers (calcium, parathormone, alkaline phosphatase, telopeptide) and menopausal status of females are the limitations of the study. Another limitation of our study is that we live in a geography where women are covered and little exposured to the sun. This may have affected the outcome of vitamin $\mathrm{D}$ in female patients.

\section{Conclusion}

We have found high vit D levels in AA group than TE and controls. The studies conducted on a larger patient population 
with vitamin-D level will most likely to be guiding the further research in a better way. Revealing the relationship between vitamin-D level and hair loss might give us the opportunity to come up with new treatment options considering refractory patients.

Disclosures: There is no conflict of interest for all authors.

\section{References}

1. Herskovitz I, Tosti A. Female Pattern Hair Loss. Int J Endocrinol Metab. 2013; 11:9860.https://doi.org/10.5812/ijem.9860

2. Dawber RPR, Ebling FJG, Wojnarowska FT. Disorders of hair. Textbook of dermatology. Ed. Champion RH, Burton JL, Ebling FJG. 5. Eddition. Oxford, Blackwell ScientificPubl, 1992; 2533-638.

3. Lolli F, Pallotti F, Rossi A, Fortuna MC, Caro G, Lenzi A, Sansone A, Lombardo F. Androgenetic alopecia: a review. Endocrine. 2017; 57(1):9-17. https://doi.org/10.1007/s12020-017-1280-y

4. Hillmer AM, Hanneken S, Ritzmann S, Becker T, Freudenberg J, Brockschmidt FF, et al. Genetic variation in the human androgen receptor gene is the major determinant of common early-onset androgenetic alopecia. Am J Hum Genet. 2005; 77(1):140-8. https://doi.org/10.1086/431425

5. Kelly Y, Blanco A, Tosti A. Androgenetic Alopecia: An Update of Treatment Options. Drugs. 2016; 76(14):1349-64. https://doi. org/10.1007/s40265-016-0629-5

6. Saitoh M, Uzuka M, Sakamoto M. Human haircycle. J Invest Dermatol. 1970; 54:65-81. https://doi.org/10.1111/1523-1747. ep12551679

7. Malkud S. Telogen Effluvium: A Review. J Clin Diagn Res. 2015; 9(9):WE01-3. https://doi.org/10.7860/JCDR/2015/15219.6492

8. Grover C, Khurana A. Telogen effluvium. Indian J Dermatol Venereol Leprol. 2013; 79(5):591-603. https://doi.org/10.4103/03786323.116731

9. Rebora A. Intermittent Chronic Telogen Effluvium. Skin Appendage Disord. 2017; 3(1):36-38. https://doi.org/10.1159/000455882

10. Gerkowicz A, Chyl-Surdacka K, Krasowska D, Chodorowska G. The Role of Vitamin D in Non-Scarring Alopecia. Int J Mol Sci. 2017; 18(12):E2653. https://doi.org/10.3390/ijms18122653

11. Cash TF: The psychosocial consequences of androgenic alopecia: a review of the research literature. Br J Dermatol. 1999; 141:398-405. https://doi.org/10.1046/j.1365-2133.1999.03030.x

12. Kutlubay Z, Bağlam S, Engin B, Serdaroğlu S. Erkeklerde androgenetik alopesi. Türkderm. 2014; 48:36-9.

13. Hamilton JB: Male hormone stimulation is prerequisite and an incitant in common baldness. Am J Anat. 1942; 71:451-80. https:// doi.org/10.1002/aja.1000710306

14. Headington JT. Telogen effluvium. New concepts and review. Arch Dermatol. 1993; 129(3):356-363. https://doi.org/10.1001/ archderm.1993.01680240096017

15. Whiting DA. Chronic telogen effluvium: increased scalp hair shedding in middle-aged female. J Am Acad Dermatol. 1996; 35(6):899- 906. https://doi.org/10.1016/S0190-9622(96)90113-9

16. Myszka M, Klinger M. The immuno modulatory role of Vitamin D. Postepy Hig Med Dosw (Online). 2014;68:865-78 https:// doi.org/10.5604/17322693.1110168

17. Morimoto S, Kumahara Y. A patient with psoriasis cured by 1 alpha-hydroxy VitD3. Med J Osaka Univ 1985;35:51-4

18. Parsad D, Saini R, Nagpal R. Calcipotriol in vitiligo: a preliminary study. Pediatr Dermatol. 1999; 16:317-20. https://doi. org/10.1046/j.1525-1470.1999.00083.X

19. Cunningham BB, Landells ID, Langman C, Sailer DE, Paller AS. Topical calcipotriene for morphea/linearscleroderma. $J$ Am Acad Dermatol. 1998; 39:211-36. https://doi.org/10.1016/S0190-9622(98)70077-5

20. Wegienka G, Havstad S, Zoratti EM, Kim H, Ownby DR, Johnson C C. Association between vitamin D levels and allergy-related outcomes vary by race and other factors. J Allergy Clin Immunol. 2015;136(5):1309-14. https://doi.org/10.1016/j.jaci.2015.04.017

21. Mirzakhani H, Al-Garawi A, Weiss ST, Litonjua AA. Vitamin D and the development of allergic disease: how important is it? Clin Exp Allergy. 2015; 45(1):114-25. https://doi.org/10.1111/cea.12430

22. Sakai Y, Kishimoto J, Demay MB: Metabolic and cellular analysis of alopecia in vitamin D receptor knock out mice. J ClinInvest. 2001; 107:961- 6. https://doi.org/10.1172/JCI11676

23. Mady LJ, Ajibade DV, Hsaio C, Teichert A, Fong C, Wang Y, et al. The Transient Role for Calcium and Vitamin D during the Developmaletal Hair Follicle Cycle. J Invest Dermatol. 2016; 16: S0022-202X(16)30876-4. https://doi.org/10.1016/j. jid.2016.02.813

24. Xie Z, Komuves L, Yu QC, Elalieh H, Ng DC, Leary C, et al. Lack of the vitamin D receptor is associated with reduced epidermal differentiation and hair follicle growth. J Invest Dermatol. 2002;118(1):11-6. https://doi.org/10.1046/j.1523-1747.2002.01644.x

25. Beer S, Tieder M, Kohelet D, et al: Vitamin D resistant rickets with alopecia: A form of end organ resistanceto 1,25 dihydroxy vitamin D. Clin Endocrinol. 1981; 14:395-402. https://doi.org/10.1111/j.1365-2265.1981.tb00626.x

26. Mahamid M, Abu-Elhija O, Samamra M, Mahamid A, Nseir W. Association between vitamin D levels and alopecia areata. Isr Med Assoc J. 2014; 16(6):367-70.

27. Fawzi MM, Mahmoud SB, Ahmed SF, Shaker OG. Assessmalet of vitamin D receptors in alopecia areata and androgenic alopecia. J Cosmet Dermatol. 2016; https://doi.org/10.1111/jocd.12224

28. H. Rasheed a D. Mahgoub a R. Hegazy a M. El-Komy a R. Abdel Hay a M.A. Hamid a E. et al. Serum Ferritinand Vitamin D in Female Hair Loss: Do They Play a Role? Skin Pharmacol Physiol. 2013; 26:101-107.https://doi.org/10.1159/000346698

How to cite this article: Gülbahar Saraç, Tuba Tülay Koca The importance of vitamin-D in androgenic alopecia and telogen effluvium. J Clin Med Kaz. 2018; 4(50):26-29 